\title{
Manajemen Anestesi pada Pasien Seksio Sesarea Primigravida 35 Minggu dengan Sindroma Nefrotik
}

\author{
Roni Kartapraja, Bambang Suryono Suwondo \\ Departemen Anestesiologi dan Terapi Intensif Fakultas Kedokteran, Kesehatan Masyarakat dan Keperawatan \\ Universitas Gadjah Mada Yogyakarta
}

\begin{abstract}
Abstrak
Sindroma nefrotik adalah sekumpulan gejala berupa proteinuria, hipoalbuminemia, edema, hiperkolesterolemia, dan lipiduria yang ditandai peningkatan permeabilitas dinding kapiler terhadap protein serum. Sindroma nefrotik pada kehamilan jarang terjadi namun bila tidak dikelola dengan baik akan meningkatkan morbiditas. Sindroma anefrotik dapat muncul sebelum umur kehamilan 20 minggu dan sering disebabkan oleh glomerulonephritis, sedangkan yang muncul sesudah umur kehamilan 20 minggu patut diduga disebabkan atau disertai suatu preeklampsia. Dilaporkan pasien 35 minggu dengan diagnosis preeklamsia, sindroma nefrotik dan suspek edema pulmo. Pasien di diagnosis sindroma nefrotik sejak kehamilan 12 minggu dan mendapat terapi metilprednisolone 16 mg 1-0-0 hingga sekarang. Pada usia kehamilan 28 minggu pasien didiagnosis preeklamsia. Datang karena kontraksi yang semakin kencang. Pasien dilakukan seksio sesarea dengan tehnik regional anestesi epidural Levobupivacain $0.5 \%$ isobarik $11 \mathrm{ml}$, janin cukup viable dilahirkan. Pasca operasi pasien dirawat di high care unit dan pulang ke rumah setelah perawatan 8 hari dalam kondisi baik. Manajemen anestesia pada ibu hamil dengan sindroma nefrotik antara lain sering disertai tekanan darah tinggi atau preeklampsia, malnutrisi dan hilangnya zat-zat yang diperlukan tubuh bersamaan dengan hilangnya protein melalui urine. Pasien seharusnya ditangani melalui pendekatan multidisipliner dengan spesialis perinatologi, nefrologi, dan neonatologi, dengan pemahaman terhadap pentingnya menjaga keseimbangan agar sesuai dengan perubahan fisiologis wanita hamil normal akan memberikan prognosis yang baik dalam menurunkan tingkat morbiditas.
\end{abstract}

Kata kunci: hipoalbuminemia, proteinuria, sindroma nefrotik

\section{Anesthesia Management of Caesarean Section in 35 Weeks Primigravida Patients with Nephrotic Syndrome}

\begin{abstract}
Nephrotic syndrome is a set of symptoms in the form of proteinuria, hypoalbuminemia, edema, hypercholesterolemia, and lipiduria which are characterized by an increase in capillary wall permeability to serum proteins. Nephrotic syndrome in pregnancy is rare but if not managed properly, it will increase a morbidity. Nephrotic syndrome can occur before 20 weeks of gestation and is often caused by glomerulonephritis, whereas if appears after 20 weeks' gestation is thought to be due to or accompanied by preeclampsia. A 35-week patient was reported with preeclampsia, nephrotic syndrome and suspected pulmonary edema. Patients were diagnosed with nephrotic syndrome since 12 weeks' gestation and were treated with methylprednisolone $16 \mathrm{mg} 1-0-0$ until now. At 28 weeks' gestation the patient was diagnosed with preeclampsia. she came to hospital due to primature contraction. Patient underwent SC with a $11 \mathrm{ml}$ Levobupivacaine $0.5 \%$ drug isobaric epidural anesthesia regional technique, the fetus was viable enough to be born. After surgery the patient was treated at HCU and returned home after 8 days of treatment in good condition. Management of anesthesia in pregnant women with nephrotic syndrome is often accompanied by high blood pressure or preeclampsia, malnutrition and loss of substances needed by the body along with loss of protein through urine. Patients should be treated through a multidisciplinary approach, along with specialists in perinatology, nephrology, and neonatology. With an understanding of the importance of maintaining balance in accordance with the physiological changes of normal pregnant women will provide a good prognosis in reducing morbidity.
\end{abstract}

Key words: hypoalbuminemia, proteinuria, nephrotic syndrome 


\section{Pendahuluan}

Sindroma nefrotik adalah sekumpulan tanda dan gejalayang menyertaipenyakitglomerular tertentu yang ditandai oleh peningkatan permeabilitas dinding kapiler terhadap protein serum. Ciri khas sindroma nefrotik adalah proteinuria lebih dari 3 gram per 24 jam, hipoalbuminemia, edema, hiperlipidemia, dan lipiduria dapat terjadi akibat proteinuria. Sindroma nefrotik biasanya tidak terlihat saat onset, dan fungsi ginjal sering kali normal pada saat pasien berkunjung ke dokter atau klinik. Pada dua pertiga orang dewasa dan sebagian besar anak-anak, sindroma nefrotik merupakan manifestasi dari salah satu dari tiga bentuk penyakit glomerular primer: glomerulosklerosis, nefroparti membranosa, dan lipoid nefrosis. ${ }^{1}$ Sindroma nefrotik jarang terjadi selama kehamilan. Sindroma nefrotik ditemukan pada $0,012 \%$ hingga $0,025 \%$ dari semua kehamilan. Penyebab utama proteinuria nefrotik dalam kehamilan adalah preeklampsia. Dengan demikian, penyebab sindroma nefrotik dalam kehamilan (khususnya pada usia kehamilan $>20$ minggu) harus dipertimbangkan sebagai preeklampsia hingga terbukti sebaliknya. Adapun penyebab proteinuria non-preeklamptik dalam kehamilan diantaranya disebabkan oleh diabetes, lupus nephritis, IgA nefropati, penyakit ginjal seperti reflux nephropathy, penyakit ginjal polikistik, interstitial nephritis, dan glomerulonefritis yang terkait obat atau infeksi. ${ }^{2}$ Pasien yang datang dengan proteinuria sebelum usia kehamilan 20 minggu seharusnya dicurigai memiliki glomerulonefropati. Biopsi ginjal biasanya aman dalam kelompok pasien ini dan berguna dalam memandu manajemen, tetapi seleksi pasien yang memenuhi syarat untuk biopsi harus dilakukan dengan hati-hati. Risiko komplikasi biopsi selama kehamilan secara umum rendah, tetapi ada kemungkinan meningkatnya potensi yang merugikan pada janin jika efek samping terjadi, khususnya setelah usia kehamilan 24 minggu saat janin sudah viable. ${ }^{3}$

Tanpa diagnosis histologis, insidensi sindroma nefrotik akibat penyakit glomeruler primer masih belum jelas karena kesulitan dalam membedakannya dari preeklampsia, dan kemungkinan adanya komorbiditas penyakit glomerular primer bersama dengan preeklampsia. ${ }^{3}$

\section{Kasus}

Pasien seorang wanita,usia 28 tahun, gravida 1 para 0 abortus 0 hamil 35 minggu, dengan sindroma nefrotik dan preeklampsia berat (PEB). Pasien datang karena keluhan kontraksi yang semakin menguat. Gerakan janin masih aktif. Lender darah dan ketuban belum keluar. Enam bulan sebelum masuk rumah sakit saat umur kehamilan 12 minggu pasien mengeluhkan bengkak di kedua kaki, badan dan wajah. Periksa ke dokter kemudian di diagnosis sindroma nefrotik dan mendapat terapi metil prednisolon 16 mg 1-0-0 hingga sekarang. Bengkak masih ada namun berkurang. Pasien melakukan antenatal care rutin di poli kebidanan. Tekanan darah tinggi sejak usia kehamilan 28 minggu dan di diagnosis PEB, sindroma nefrotik, suspek oedema pulmo. Keluhan batuk berdahak sejak 1 minggu yang lalu. Nyeri kepala, pandangan kabur, mual muntah, nyeri ulu hati disangkal. Pada pemeriksaan fisik didapatkan kesadaran Glasgow Coma Scale (GCS) 15 E4M6V5, jalan nafas bebas, tekanan darah 150/100 $\mathrm{mmHg}$, nadi 116 kali per menit, frekuensi nafas 26 kali per menit, suhu $36,5^{\circ} \mathrm{C}$. Pemeriksaan status generalis menunjukkan Mallampati II, konjungtiva tidak anemis, sklera tidak ikterik, paru-paru terdengar ronchi di kedua lapang paru, tungkai tidak edema. Pemeriksaan jantung, dan vertebra tidak terdapat kelainan. Dari pemeriksaan ophthalmologist tidak ditemukan papill edema.

Hasil laboratorium didapatkan kadar hemoglobin $9.4 \mathrm{gr} \%$, hematokrit $29.3 \%$, leukosit $15.000 \mathrm{mg} /$ $\mathrm{dL}$, trombosit $395.000 \mathrm{mg} / \mathrm{dL}$, GDS $137 \mathrm{mg} / \mathrm{dL}$. Kadar enzim hepar SGOT $350 \mathrm{IU} / \mathrm{L}$ dan SGPT $285 \mathrm{IU} / \mathrm{L}$. Ureum $8 \mathrm{mg} / \mathrm{dL}$ dan kretinin 0.93 $\mathrm{mg} / \mathrm{dL}$. Dari pemeriksaan urinalisis didapatkan protein +4 , leukosit $216 / \mu \mathrm{L}$, eritrosit $1184 / \mu \mathrm{L}$. Pasien didiagnosis ASA 3 PEB, sindroma nefrotik dan suspek pulmo edema. Tindakan anestesia yang dipilih pada pasien ini adalah dengan regional anestesi epidural. Setelah dilakukan informed consent dilakukan pemasangan monitor untuk memantau tanda vital pasien selama operasi. 
Pasien masuk kamar operasi, dilakukan pemasangan monitor untuk tekanan darah, EKG, pulse oxymetri. Terbaca di monitor tekanan darah $150 / 100 \mathrm{mmHg}$, laju nadi $102 \mathrm{x} / \mathrm{menit}$, laju nafas 20x/menit $\mathrm{SpO}_{2}$ 98\%. Pemberian oksigen melalui nasal kanul $3 \mathrm{lpm}$. Tehnik anestesi dengan regional epidural. Pemasangan selang kateter dari posisi duduk. Penusukan setinggi L3-L4 lost of resistance (+), jarum Tuohy no.18 G. Dilakukan pemberian test dose (lidokain $0.15 \%$ + epinephrine 1:20.000) dengan tes volume 3 cc. Setelah memastikan kateter epidural aman, dilakukan pemberian Levobupivacain $0.5 \%$ isobaric $11 \mathrm{ml}$ secara titrasi. Pin prick tercapai setinggi Th VI. Bayi lahir 2 menit setelah insisi kulit, oksitosin 10 IU diberikan secara drip melalui cairan RL. Berat bayi 1710 gr, Panjang badan $42 \mathrm{~cm}$, lingkar kepala $29 \mathrm{~cm}$, lingkar dada $26 \mathrm{~cm}$. Selama operasi tekanan darah sistolik 150-100 mmHg, tekanan diastolik 60-93 $\mathrm{mmHg}$, laju nadi $90-110 x /$ menit, laju nafas $18-20 x /$ menit $\mathrm{SpO}_{2}$ 98-100\% dengan $\mathrm{O}_{2}$ nasal kanul $3 \mathrm{lpm}$. Operasi berlangsung selama 1 jam. Perdarahan $500 \mathrm{ml}$. urin output (uo): $0,4 \mathrm{cc} / \mathrm{kg} / \mathrm{jam}$.

Pasca operasi pasien dirawat di high care unit (HCU). Diberikan obat analgetik epidural levobupivakain $0,125 \% 3 \times 8 \mathrm{cc}$, paracetamol $3 \times 1$ gram IV hari pertama, furosemide $3 \mathrm{mg} /$ jam, metildopa $3 \times 500 \mathrm{mg}$ p.o. Selama perawatan di $\mathrm{HCU}$ hemodinamik terkontrol, $\mathrm{SpO}_{2}$ 98100\% dengan nasal kanul $3 \mathrm{lpm}$. Pemeriksaan laboratorium pasca operasi didapatkan kadar hemoglobin 9,1 gr\%, ureum $10 \mathrm{mg} / \mathrm{dL}$ dan kreatinin $0.74 \mathrm{mg} / \mathrm{dL}$. Hari perawatan ke 2 hemodinamik relatif stabil, urine output: 0,5$0,7 \mathrm{cc} / \mathrm{kg} / \mathrm{jam}$ dengan balanced carian harian sekitar $500 \mathrm{cc}$ dan balanced cairan komulatif selama di HCU sekitar $850 \mathrm{cc}$. Setelah perawatan 2 hari di HCU pasien pindah ruangan biasa.

\section{Pembahasan}

Sindroma nefrotik didefinisikan secara klasik sebagai proteinuria nefrotik ( $>3 \mathrm{~g} /$ hari) dengan hipoalbuminemia (albumin serum $<30 \mathrm{~g} / \mathrm{L}$ ), edema, hiperkolesterolemia, dan lipiduria. Perlu diketahui, bahwa pada kehamilan normal, kadar albumin menurun secara progresif dari rerata
$38 \mathrm{~g} / \mathrm{L}$ pada usia kehamilan 12 minggu menjadi $32 \mathrm{~g} / \mathrm{L}$ pada 36 minggu, dan kadar kolesterol meningkat dari rerata $4,48 \mathrm{mmol} / \mathrm{L}(173 \mathrm{mg} /$ dL) pada usia kehamilan 12 minggu menjadi $6,63 \mathrm{mmol} / \mathrm{L}(256 \mathrm{mg} / \mathrm{dL})$ pada usia kehamilan 36 minggu. Penting untuk ditekankan bahwa kadar proteinuria yang tinggi tidak selalu berakibat pada hipoalbuminemia dan sindroma nefrotik. Saat mendiagnosis sindroma nefrotik, perlu dinilai konsekuensi klinis yang menyertai hipoalbuminemia dan penurunan tekanan onkotik, seperti edema perifer, asites, dan efusi pleura/ perikardial. ${ }^{4}$ Wanita dengan sindroma nefrotik biasanya memiliki edema. Akan tetapi, ini adalah tanda yang sangat nonspesifik selama kehamilan karena kemunculannya ditemukan pada dua pertiga kehamilan normal. Biasanya edema dapat ditangani dengan mudah menggunakan langkahlangkah konservatif seperti penggunaan stocking, membatasi garam diit hingga tidak lebih dari $100 \mathrm{mmol} /$ hari (2,3 g natrium) dan pembatasan cairan hingga sekitar 1,5 L/hari. Akan tetapi, dalam sindroma nefrotik berat, edema perifer dan anasarka dapat menimbulkan rasa tidak nyaman dan masalah lain, seperti kesulitan untuk berjalan, kesembuhan luka dan komplikasi kulit sekunder, edema genital berat, kesulitan napas karena efusi pleura, peningkatan risiko edema pulmoner nonkardiogenik, kesulitan anestesi regional karena edema lumbal, atau komplikasi postoperatif karena terbukanya luka irisan operasi sesarea. Beberapa pasien mungkin akan memerlukan diuretik harian, dengan dosis awal 5-10 mg. Loop diuretic seperti furosemid adalah yang paling sering dipilih sebagai duretik awal., ${ }^{2,4}$

Monitoring ketat terhadap berat badan, elektrolit (natrium, kalium, kalsium, dan magnesium) dan bikarbonat (untuk menghindari alkalosis karena diuretik), keseimbangan cairan, dan tekanan darah mungkin diperlukan secara harian hingga TD stabil dan keseimbangan cairan dan elektrolit tercapai dengan diuretik. Serial fetal growth scan penting jika akan menggunakan diuretik pada kehamilan. ${ }^{4}$ Penggunaan albumin intravena untuk memperbaiki tekanan onkotik intravaskular masih menjadi kontroversi, penggunaan albumin intravena untuk hipotensi dan kenaikan kreatinin serum tetapi efeknya selalu bersifat sementara; 
tidak ada indikasi penggunaan albumin intravena untuk meningkatkan kadar albumin serum. Penggunaan koloid tidak direkomendasikan kecuali dalam kondisi yang luar biasa. ${ }^{2,4}$

Hipoalbuminemia berat (albumin $<25$ g/L) juga telah dikaitkan dengan peningkatan risiko kejadian tromboemboli vena, dan kehamilan sendiri adalah keadaan protrombotik. Trombosis vena renalis telah dilaporkan muncul pada sindroma nefrotik dalam kehamilan, menyebabkan perburukan fungsi renal. Seperti halnya perubahan fisiologis faktor hemostatik yang menyebabkan kondisi protrombotik dalam kehamilan, risiko trombosis semakin meningkat dalam sindroma nefrotik karena beberapa faktor. Faktor-faktor tersebut antara lain peningkatan protein antikoagulan yang hilang lewat urin (seperti antitrombin), peningkatan sintesis faktor pembekuan darah hepatik, hipovolemia intravaskular dalam tingkatan tertentu (kebocoran cairan interstisial, dan kombinasi pembatasan garam/air dan penggunaan diuretik), inflamasi serta penurunan mobilisasi karena edema perifer dan ketidaknyamanan. ${ }^{4}$ Meski ada konsensus bahwa tromboprofilaksis diperlukan dalam situasi berisiko tinggi, kapan seharusnya memulai profilaksis tersebut dalam sindroma nefrotik masih menjadi perdebatan. Pendapat ahli mengusulkan bahwa pasien wanita dengan proteinuria berat dan albumin serum $<20 \mathrm{~g} / \mathrm{L}$ seharusnya mendapatkan tromboprofilaksis sepanjang kehamilan.

Pemberian antikoagulasi perlu dipertimbangkan pada pasien dengan sindroma nefrotik yang lebih ringan namun disertai faktor risiko tambahan seperti obesitas, imobilitas, membranous nephropathy, atau vaskulitis. Pemilihan obat antikoagulan dan regimen dosis sama dengan kondisi medis lainnya. Low molecular weight heparin bisa diberikan dengan syarat glomerulo filtration rate (GFR) mendekati normal, yaitu di atas $60 \mathrm{~mL} / \mathrm{menit}$, dan unfractionated heparin mungkin bisa digunakan untuk pasien dengan GFR di bawah $60 \mathrm{~mL} /$ menit. $^{1}$ Perlu dipertimbangkan kemungkinan efek samping terapi serta masalah-masalah yang sering muncul, khususnya sekitar persalinan, seperti risiko perdarahan dan kebutuhan untuk anestesi regional atau operasi caesar. ${ }^{4}$

Biopsi ginjal tidak dikontraindikasikan pada kehamilan, tetapi seharusnya dipertimbangkan hanya ketika informasi yang didapatkan dari pemeriksaan biopsi sepertinya akan mempengaruhi pendekatan pengobatan. Meski demikian, gambaran klinis proteinuria yang signifikan de novo atau sindroma nefrotik pada awal kehamilan (selama trimester pertama atau kedua) biasanya memerlukan biopsi renal untuk menentukan diagnosis dan memandu terapi immunosupresi, dan dianggap aman selama tekanan darah terkendali. ${ }^{5}$ Keputusan untuk melakukan biopsi ginjal selama kehamilan sering disertai dengan kekhawatiran, karena prosedur ini tidak hanya menyebabkan risiko pada pasien, tetapi juga pada janin. Indikasi untuk biopsi ginjal antara lain perburukan mendadak dalam fungsi ginjal, sindroma nefrotik de novo dan/ atau kecurigaan glomerulonefritis. Data tentang keamanan biopsi ginjal dalam kehamilan masih terbatas.

Sebuah meta-analisis terhadap 39 penelitian menemukan insidensi komplikasi yang lebih tinggi pada biopsi antepartum dibandingkan postpartum. Akan tetapi, sebagian besar komplikasi ini minor, seperti nyeri pinggang dan hematuria makroskopis. Komplikasi signifikan terjadi pada periode usia kehamilan 23-2 minggu, dimana terdapat peningkatan kasus perdarahan mayor. Biopsi ginjal selama kehamilan hanya direkomendasikan ketika ada kecurigaan penyakit glomerular signifikan dimana diagnosis akan mengubah terapi. Seiring berlanjutnya kehamilan, posisi tengkurap yang biasanya dilakukan untuk biopsi menjadi tidak memungkinkan dan mungkin memerlukan posisi dekubitus lateral atau duduk. Skenario ini biasanya dihindari, karena risiko sering kali melebihi manfaat dari penegakan diagnosis setelah usia kehamilan 30-32 minggu. ${ }^{6-9}$ Pengendalian tekanan darah bergantung pada kondisi yang mendasari sindroma nefrotik, tekanan darah bisa tinggi, normal, atau bahkan rendah. Ketika menangani hipertensi, harus diperhatikan keseimbangan antara penurunan tekanan darah 
hingga tingkat yang cukup untuk melindungi ginjal tetapi tidak mengganggu aliran darah uteroplasenta. Meskipun ada kecemasan tentang penurunan pertumbuhan janin jika tekanan darah terlalu rendah pada kehamilan hipertensif, sejauh ini belum ada data yang secara khusus terkait sindroma nefrotik. Target tekanan darah pada pasien hamil dengan sindroma nefrotik masih menjadi kontroversi, Cote \& Sauve menargetkan menargetkan tekanan darah $<130 / 80 \quad \mathrm{mmHg}$ pada sindroma nefrotik tetapi berusaha untuk menghindari penurunan tekanan darah terlalu besar dengan terapi antihipertensif $(<110 / 70$ $\mathrm{mmHg}$ ) ketika terdapat penurunan volume darah yang efektif. Pihak lain menargetkan tekanan darah 110-140/80-90 mmHg. ${ }^{6}$ Target tekanan darah seharusnya ditentukan secara individual pasien sesuai dengan kondisi klinis dan riwayat ginjal pra-kehamilan. ${ }^{4}$ Metildopa dan labetalol adalah antihipertensi lini pertama pilihan dalam kehamilan. ${ }^{2}$

Suplemen besi, asam folat, dan vitamin B12 mungkin diperlukan untuk mengkoreksi defisiensi dan memacu retikulositosis. Terapi besi intravena mungkin diperlukan karena penurunan absorpsi sediaan oral karena edema dinding intestinal dalam sindroma nefrotik. ${ }^{2}$ Jika iron loading diperlukan, direkomendasikan iron sucrose intravena, $200 \mathrm{mg} /$ dosis yang diberikan selama beberapa hari. ${ }^{4,9}$ Malnutrisi dapat terjadi dalam sindroma nefrotik ketika kehilangan protein dan nutrien lainnya yang signifikan melalui urin dan/atau penurunan absorpsi intestinal karena edema dinding intestinal. Inflamasi akibat glomerulonefritis mungkin juga berkontribusi terhadap peningkatan katabolisme maternal. Malnutrisitidakjarang ditemukan dalam sindroma nefrotik, khususnya protein, dan dianjurkan untuk melibatkan peran serta ahli gizi. ${ }^{2,4}$ Sindroma nefrotik jarang menyebabkan komplikasi dalam kehamilan jika hipertensi dan fungsi ginjal yang abnormal tidak ditemukan. Perawatan prenatal, monitoring janin, dan manajemen persalinan seharusnya mengikuti rekomendasi untuk insufisiensi renal kronis. Pasien seharusnya ditangani melalui pendekatan multidisipliner, bersama dengan spesialis perinatologi, nefrologi, dan neonatologi. ${ }^{7}$ Frekuensi kunjungan klinis dan monitoring laboratorium perlu ditentukan secara individual dan berdasarkan per kasus. ${ }^{2}$

Seperti kondisi medis lain dalam kehamilan, keputusan untuk melakukan persalinan harus ditentukan secara individual dan setelah diskusi multidisipliner dengan mempertimbangkan usia kehamilan, kondisi dan prognosis ibu/janin terkini, risiko komplikasi karena melanjutkan kehamilan versus risiko komplikasi karena persalinan dini. Perburukan fungsi ginjal yang perlahan atau mendadak yang mungkin tidak akan membaik dapat menjadi pertimbangan persalinan dini. ${ }^{10}$ Meski kadar proteinuria sendiri tidak dianggap sebagai indikasi untuk persalinan, edema berat/anasarka yang tidak terkendali dengan komplikasi signifikan yang tidak merespon terhadap pemberian obat atau ketidakmampuan untuk memonitor tekanan darah, atau memperoleh akses vena mungkin juga bisa dianggap sebagai indikasi untuk persalinan. 4,6,10 Preeklampsia atau hipertensi yang tidak terkendali merupakan indikasi untuk persalinan karena potensi morbiditas berat dan mortalitas maternal dan fetal.

Ketika waktu persalinan telah tercapai ( $>3$ minggu) atau jika risiko prematuritas fetal rendah sesuai dengan hasil penilaian dan pengalaman lokal, persalinan bisa dipertimbangkan untuk menurunkan risiko maternal serius. Komplikasi fetal yang mengkhawatirkan (paling sering adalah perlambatan pertumbuhan janin) atau kondisi obstetrik lain yang signifikan mungkin mendorong dilakukannya persalinan. ${ }^{4,6,8}$ Setelah persalinan, perubahan fisiologis yang dipicu kehamilan akan kembali ke kondisi pra-kehamilan dalam hitungan jam, hari, atau bahkan bulan. Akan tetapi, perlu diawasi kemungkinan terjadinya preeklampsia postpartum, kemungkinan perburukan fungsi ginjal, dan peningkatan tekanan darah postparum. Oleh karena itu, surveillance maternal ketat (baik klinis dan laboratorik) masih menjadi hal penting. ${ }^{4}$ Diuresis spontan sering terjadi, kadang mencapai beberapa liter per hari, dengan perbaikan edema yang cepat. Oleh karena itu, restriksi garam dan cairan atau kebutuhan terhadap diuretik perlu dievaluasi kembali setiap hari dalam beberapa hari pertama setelah persalinan. ${ }^{2}$ Prognosis untuk keberhasilan kehamilan tanpa perburukan 
dalam fungsi ginjal tergantung pada penyebab sindroma nefrotik. Sindroma nefrotik jarang menyebabkan komplikasi dalam kehamilan jika hipertensi dan fungsi ginjal yang abnormal tidak ditemukan. Perawatan prenatal, monitoring janin, dan manajemen persalinan seharusnya mengikuti rekomendasi untuk insufisiensi renal kronis. Pasien seharusnya ditangani melalui pendekatan multidisipliner, bersama dengan spesialis perinatologi, nefrologi, dan neonatologi. ${ }^{7,910}$ Frekuensi kunjungan klinis dan monitoring laboratorium perlu ditentukan secara individual dan berdasarkan per kasus. ${ }^{2}$ Prognosis jangka panjang tergantung pada diagnosis spesifik. Sebagian besar bukti yang ada menunjukkan bahwa kehamilan tidak memperburuk atau mempercepat proses penyakit pada wanita dengan penyakit glomerular primer, setidaknya pada setelah pemantauan selama lima tahun. ${ }^{2}$ Komplikasi yang mungkin muncul pada janin mencakup growth restriction, prematuritas, kematian janin, fetal anasarca, dan polihidramnion. Dalam sindroma nefrotik, fetal growth restriction kemungkinan besar berhubungan dengan berkurangnya perfusi uteroplasental akibat tekanan osmotik koloid rendah dan penurunan dalam volume darah efektif. ${ }^{3}$

\section{Simpulan}

Sindroma nefrotik pada kehamilan jarang terjadi namun apabila tidak dikelola dengan baik akan meningkatkan morbiditas maternal dan janin. Pasien seharusnya ditangani melalui pendekatan multidisipliner, bersama dengan spesialis perinatologi, nefrologi, dan neonatologi. Sindroma nefrotik dapat muncul sebelum umur kehamilan 20 minggu dan sering disebabkan oleh glomerulonefritis, sedangkan sindroma nefrotik yang muncul sesudah umur kehamilan 20 minggu patut diduga disebabkan atau disertai suatu preeklampsia. Walaupun hingga saat ini literatur mengenai sindroma nefrotik masih sangat sedikit dan sebagian besar pembahasan merupakan pengalaman kasus namun dengan pemahaman terhadap pentingnya menjaga keseimbangan agar sesuai dengan perubahan fisiologis wanita hamil normal akan memberikan prognosis yang baik dalam menurunkan tingkat morbiditas wanita hamil dengan sindroma nefrotik.

\section{Daftar Pustaka}

1. Brown MA, Mangos GJ, Peek M, Plaat F. Renal disease in pregnancy. In: Powrie RO, editor. De Swiet's medical disorders in obstetric practice. 5th ed. Oxford : WileyBlackwell ; 2010.

2. Narayan H. Compendium for the antenatal care of high-risk pregnancies [Internet]. 2015 [cited 2018 Feb 17]. Tersedia dari : http:// www.search.ebscohost.com/login. aspx?direct $=$ true $\&$ scope $=$ site $\& d b=$ nlebk\&d $\mathrm{b}=$ nlabk\&AN $=1028707$

3. De Castro I, Easterling TR, Bansal N, Jefferson JA. Nephrotic syndrome in pregnancy poses risks with both maternal and fetal complications. Kidney Int. 2017 Jun ; 91(6) : 1464-72.

4. Côté AM, Sauvé N. The management challenges of non-preeclampsia-related nephrotic syndrome in pregnancy. Obstet Med. 2011 Dec ; 4(4) : 133-9.

5. Blom K, Odutayo A, Bramham K, Hladunewich MA. Pregnancy and Glomerular Disease: A Systematic Review of the Literature with Management Guidelines. Clin J Am Soc Nephrol CJASN. 2017 Nov 7; 12(11) : 1862-72.

6. Hladunewich MA, Bramham K, Jim B, Maynard S. Managing glomerular disease in pregnancy. Nephrol Dial Transplant. 2017 Jan 1 ; 32(suppl_1) : i48-56.

7. McCurdy R. Renal disease. In: Berghella $\mathrm{V}$, editor. Maternal-fetal evidence based guidelines [Internet]. 2017 [cited 2018 Feb 17]. Tersedia dari: https://doi. org/10.1201/9781315200910

8. Wei Q, Zhang L, Liu X. Outcome of severe preeclampsia manifested as nephrotic syndrome. Arch Gynecol Obstet. 2011 Feb ; 
283(2) : 201-4.

9. Hnat M, Sibai B. Renal Disease and Pregnancy. Glob Libr Womens Med [Internet]. 2009 [cited2018Feb12]; Tersedia dari : http:// www.glowm.com/index.html?p=glowm.cml/ section_view\&articleid $=157$.
10. South AM, Nixon PA, Chappell MC, Diz DI, Russell GB, Snively BM, Shaltout HA et al. Antenatal corticosteroid and the reninangiuotensinaldosterone system in adolescent born pretem. Int Ped Research Found. 2017; 88-93. 